\title{
Correction to: Micronized sacchachitin promotes satellite cell proliferation through TAK1-JNK-AP-1 signaling pathway predominantly by TLR2 activation
}

\author{
Meng-Huang Wu ${ }^{1,2}$, Chuang-Yu Lin ${ }^{3}$, Chun-Yin Hou ${ }^{4}$, Ming-Thau Sheu ${ }^{5^{*}}$ and Hsi Chang ${ }^{6,7^{*}}$ (1)
}

\section{Correction to: Chin Med (2020) 15:100} https://doi.org/10.1186/s13020-020-00381-3

Following publication of the original article [1], the authors would like to correct the content under Funding.

The content currently reads:

This study funded by Taipei Medical University Hospital (108TMU-TMUH-16).

The content should be changed to:

This study funded by Taipei Medical University Hospital (109TMU-TMUH-10).

The original article has been updated.

\section{Author details}

${ }^{1}$ Department of Orthopedics, Taipei Medical University Hospital, No. 252 Wuxing St., Taipei 11031, Taiwan. ${ }^{2}$ Department of Orthopedics, College of Medicine, Taipei Medical University, No. 250 Wuxing St., Taipei 11031, Taiwan. ${ }^{3}$ Department of Clinical Application, Center for IPS Cell Research and Application (CiRA), Kyoto University, 53 Kawahara-cho, Shogoin, Sakyo-Ku, Kyoto 606-8507, Japan. ${ }^{4}$ Department of Family Medicine, Taipei City Hospital, Zhongxiao Branch, No. 87 Tongde Rd., Taipei 115, Taiwan. ${ }^{5}$ School of Pharmacy, College of Pharmacy, Taipei Medical University, No. 250 Wuxing St., Taipei 11031, Taiwan. ${ }^{6}$ Department of Pediatrics, School of Medicine, College of Medicine, Taipei Medical University, No. 250 Wuxing St., Taipei 11031,
Taiwan. ${ }^{7}$ Department of Pediatrics, Taipei Medical University Hospital, No. 252 Wuxing St., Taipei 11031, Taiwan.

Published online: 04 February 2021

\section{Reference}

1. Wu MH, Lin CY, Hou CY, et al. Micronized sacchachitin promotes satellite cell proliferation through TAK1-JNK-AP-1 signaling pathway predominantly by TLR2 activation. Chin Med. 2020;15:100. https://doi. org/10.1186/s13020-020-00381-3.

\section{Publisher's Note}

Springer Nature remains neutral with regard to jurisdictional claims in published maps and institutional affiliations.

(C) The Author(s) 2021. This article is licensed under a Creative Commons Attribution 4.0 International License, which permits use, sharing, adaptation, distribution and reproduction in any medium or format, as long as you give appropriate credit to the original author(s) and the source, provide a link to the Creative Commons licence, and indicate if changes were made. The images or other third party material in this article are included in the article's Creative Commons licence, unless indicated otherwise in a credit line to the material. If material is not included in the article's Creative Commons licence and your intended use is not permitted by statutory regulation or exceeds the permitted use, you will need to obtain permission directly from the copyright holder. To view a copy of this licence, visit http://creativeco mmons.org/licenses/by/4.0/. The Creative Commons Public Domain Dedication waiver (http://creativecommons.org/publicdomain/ zero/1.0/) applies to the data made available in this article, unless otherwise stated in a credit line to the data. 